RESEARCH ARTICLE

\title{
A Study on Knowledge Level of Sugarcane Growers in Zero Budget Natural Farming Practices
}

\author{
Vishnuja $\mathbf{S}^{* 1}$ and Arunachalam $\mathbf{R}^{1}$ \\ *1Department of Agricultural Extension and Rural Sociology, Tamil Nadu Agricultural University, Coimbatore - 641003.
}

Received : $22^{\text {nd }}$ January, 2020

Revised : $07^{\text {th }}$ February, 2020

Revised : $25^{\text {th }}$ February, 2020

Accepted : $09^{\text {th }}$ March, 2020

\begin{abstract}
A study was conducted in Chittoor district of Andhra Pradesh covering two blocks with 128 selected sample respondents with the primary objective to find out the knowledge level of sugarcane growers in Zero Budget Natural Farming practices. Zero Budget Natural Farming is a recent approach widely being followed in Andhra Pradesh among major crops like paddy, groundnut, sugarcane, and vegetable crops. Sugarcane is a major commercial crop in which maximum farmers were enrolled under this' programme. The study revealed that a vast of the respondents were found to possess medium level of knowledge followed by low and high levels of knowledge on the recommended Zero Budget Natural Farming practices in sugarcane.
\end{abstract}

Keywords: Knowledge, sugarcane, farmers, zero budget natural farming.

\section{INTRODUCTION}

Across the world, agriculture is facing multiple setbacks in the form of extreme weather events like floods and drought or factors such as soil degradation, soil salinity, and water shortage. Indian farmers increasingly find themselves in a vicious cycle of debt, high production costs, high-interest rates for credit, and volatile market prices of crops. Zero Budget Natural Farming promises to end a reliance on loans and drastically cut production costs, ending the debt cycle for desperate farmers (Mural, 2016). Zero Budget Natural Farming (ZBNF) is one such low-input, climate-resilient type of farming that encourages farmers to use lowcost locally-sourced inputs, eliminating the use of artificial fertilizers, and industrial pesticides. Subhash Palekar has helped to popularize ZBNF practices across the country (Tripathi et al., 2018). ZBNF encourages the use of various kashayams (decoctions) made with cow dung, cow urine, lilac, and green chillies (Palekar, 2015). These practices have been shown to have a positive effect on the quality of the soil, improving its fertility and water retention capacity (Iraianbu, 2017). In 2015, the Government of Andhra Pradesh (GoAP) instituted the Rythu Sadhikara Samstha (RySS), a state-owned, non-profit organization to introduce ZBNF practices to all farmers in the Indian state of Andhra Pradesh (Amitendu and Paraparakath, 2019).

Zero Budget Natural Farming is a recent approach widely being followed in Andhra Pradesh among major crops like paddy, groundnut, sugarcane, and vegetable crops.

*Corresponding author's e-mail: sadhuvishnureddy444@gmail.com
Sugarcane is the major commercial crop in which more farmers are enrolled under this programme, and hence the present study has been conducted among sugarcane farmers. The farmer's level of knowledge on the recommended Zero Budget Natural Farming practices in sugarcane would help in developing appropriate strategies to strengthen the programme further. Keeping this in mind, as a pioneering effect, the present investigation has been taken up in the Chittoor district of Andhra Pradesh in order to assess the knowledge level of the sugarcane farmers on the recommended ZBNF practices.

\section{MATERIAL AND METHODS}

The ex-post facto research design was used in this study to suit the objective and type of information needed. The study was conducted in the Chittoor district of Andhra Pradesh, which has more number of sugarcane farmers enrolled under the programme of Zero Budget Natural Farming. Among the 66 Blocks, Nagari and Gangadhara Nellore Blocks were selected for the study, considering the maximum number of sugarcane farmers enrolled under the programme of Zero budget natural farming. Considering the same criteria, among the 19 villages of Nagari Block, 2 villages viz., Mangadu and M.Kothuru were selected, and among the 34 villages of the block Gangadhara Nellore, 2 villages viz., Velkuru and GD Nellore were selected for the study.

A sample of 128 farmers actively cultivating sugarcane under the Zero Budget Natural Farming Programme was selected from the above four villages by employing a proportionate random

$$
107|1-3| 103
$$


sampling method. Data were collected by using a well-structured interview schedule.

There were fifteen recommended ZBNF practices in sugarcane. All fifteen practices were considered for assessing the knowledge level of the sample respondents. Accordingly, a 'Teacher made Test' was developed and adopted as advocated by Deepika (2018). The scoring pattern adopted is given in Table 1.

Percentage analysis was done to get a meaningful interpretation of the results. Cumulative frequency method was also adopted to categorize the respondents in to low, medium, and high on their knowledge level.

\section{RESULTS AND DISCUSSION}

\section{Knowledge level of sugarcane growers on Zero Budget Natural Farming practices}

Fifteen knowledge items were selected for assessing the knowledge level of the respondents (Palekar, 2015). The results regarding the knowledge level of sugarcane farmers on the Zero Budget Natural Farming practices are furnished in Table 2.The findings of Table 2.

Table 1. The following is the scoring pattern adopted

\begin{tabular}{clr}
\hline S.No & Respondents & Score \\
\hline 1. & Correct & 2 \\
2. & Incorrect & 1 \\
\hline
\end{tabular}

revealed that cent per cent of the farmers possessed knowledge about profitable intercrops recommended in sugarcane under ZBNF. This clearly shows that the respondents have well understood the importance of the practice of growing intercrops in sugarcane as it protects the soil from the exhaustion of moisture and nutrients and also provides remunerative income throughout the year. An overwhelming majority of the respondents (96.90 per cent) had correct knowledge about the practices like setts spacing between rows and plants and the use of pheromone traps (@ $5 /$ acre). This may be due to their high farming experience.

Jeevamrutham acts as a catalytic agent that increases earthworm activity in the soil, and also helps to prevent fungal and bacterial plant diseases, as well as the Acchadana mulching improves the fertility and moisture retention capacity of the soil. Here an equal percentage of the respondents (95.30 per cent) possessed correct knowledge on these practices.

Cutting the cane at ground level is an important recommendation followed by the respondents mainly for getting high recovery rate and reduced incidence of early shoot borer. Hence 94.50 per cent of the respondents had correct knowledge of these practices. A similar percentage of the respondents also had correct knowledge of the recommended setts rate. About ninety per cent of the respondents ( 90.60 per cent) had correct knowledge about organic manures, which improve the nitrogen content of the soil. It is observed that 89.10 per cent of the respondents had correct knowledge on the recommended prominent leaf extracts to control leaf curl virus and sucking pests in sugarcane. This may be due to their high farming experience. Nearly three fourth $(76.60 \%)$ of the respondents had correct knowledge regarding sett treatment with Bijamrita in sugarcane, which helps in protecting young roots from fungus as well as from soil-borne and seed-borne diseases. The findings of the above table also revealed that 71.10 per cent of the respondents had correct knowledge regarding the recommended organic solution to control mealybugs in sugarcane by using Neemastra.

Table 2. Knowledge level of sugarcane growers on the recommended Zero Budget Natural Farming Practices

$(n=128)$

\begin{tabular}{|c|c|c|}
\hline Recommended practices & Number & Per cent \\
\hline Jeevamrutham is recommended for field preparation under ZBNF & 122 & 95.3 \\
\hline Setts rate @ 15,000 two budded setts / acre under ZBNF & 121 & 94.5 \\
\hline Maintaining $62 \mathrm{ft}$ and $82 \mathrm{ft}$ ( rows and plants ) spacing between setts under ZBNF & 124 & 96.9 \\
\hline Beejamrutham organic solution is recommended for setts treatment under ZBNF & 98 & 76.6 \\
\hline Green gram, cow pea, and potato are the profitable intercrops recommended in sugarcane under ZBNF & 128 & 100.0 \\
\hline Green manure application is the main practice for enriching the soil nutrient status & 116 & 90.6 \\
\hline Applying FYM @ 5 tonnes/acre in sugarcane under ZBNF as a basal application & 41 & 32.0 \\
\hline Pillipesara, Sunnhemp, and Diancha are prominently used green manure crops for sugarcane under ZBNF & 46 & 35.9 \\
\hline Use of pheromone traps ( Chilo infuscatellus) @ 5/acre under ZBNF for pest management & 124 & 96.9 \\
\hline $\begin{array}{l}\text { Acchadana mulching and Trash mulching are the prominent weed management practices in sugarcane } \\
\text { under ZBNF }\end{array}$ & 122 & 95.3 \\
\hline Agniastra used for the control of Borers & 80 & 62.5 \\
\hline Brahmastra @ 2-3 liters / 100 liters of water to one acre for the control of sucking pests & 63 & 49.2 \\
\hline Neemastra used to control mealybugs under ZBNF & 91 & 71.1 \\
\hline $\begin{array}{l}\text { Neem, Vitex and Datura leaf extracts are useful to control leaf curl virus and sucking pests in sugarcane } \\
\text { under ZBNF }\end{array}$ & 114 & 89.1 \\
\hline Manual harvesting is a profitable method & 121 & 94.5 \\
\hline
\end{tabular}

$107|1-3| 104$ 
Little more than sixty per cent of the respondents (62.50 per cent) had knowledge about the application of Agniastra for the control of Borers. It is also observed that about half ( 49.20 per cent) of the respondents had correct knowledge about the right dose of Brahmastra (@ 2-3 liters / 100 liters of water per acre) to control sucking pests. Further, it is observed about one third $(35.9 \%)$ of the respondents had correct knowledge about the prominently used green manure crops for sugarcane under ZBNF. Regarding the recommended dose of FYM (@10 tonnes/ha under ZBNF) as a basal dose 32.00 per cent of the respondents had correct knowledge. The above findings are in conformity with the findings of Naresh et al., 2018.

Table 3. Overall knowledge level of sugarcane growers on the recommended Zero Budget Natural Farming practices $(n=128)$

\begin{tabular}{lrr}
\hline Category & Number & Per cent \\
\hline Low & 20 & 15.60 \\
Medium & 95 & 74.20 \\
High & 13 & 10.20 \\
\hline Total & 128 & 100.00 \\
\hline
\end{tabular}

Overall knowledge level of sugarcane growers on the recommended Zero Budget Natural Farming practices

The overall knowledge level of sugarcane farmers on the recommended Zero Budget Natural Farming practices was assessed, and the findings are given in Table 3. About three-fourth of the respondents (74.2\%) were found to possess a medium level of knowledge, and $\mathbf{1 5 . 6}$ per cent of them had a low level of knowledge. The remaining respondents (10.2 per cent) had a high level of knowledge on the recommended Zero Budget Natural Farming practices in sugarcane. These results may be due to more number of training attended, vast experience in ZBNF, and their higher perception towards ZBNF. Here the intensive teaching efforts of the officials of the ZBNF programme also could have contributed to such results. The findings of the study are in line with the results obtained by Prabhu and Jahanara (2018).

\section{CONCLUSION}

It is concluded that a vast majority of the sugarcane farmers had a medium level of knowledge regarding recommended Zero Budget Natural Farming practices. In the practices viz., growing intercrops, maintaining setts spacing between rows and plants, use of pheromone traps, application of jeevamrutham, acchadana as well as trash mulching, manual harvesting, setts rate, leaf extracts to control leaf curl and sucking pests, sett treatment with bijamrita and organic solution to control mealybugs by using neemastra they possessed with higher knowledge level. In the practices viz., use agniastra for the control of borers, the right dose of brahmastra to control sucking pests, prominently used green manures and recommended basal dose of FYM they possessed a lower level of knowledge. Necessary systematic and periodic extension efforts, such as conducting method demonstrations, field visits, periodic training programmes and providing appropriate extension literature on the above practices in which the respondents were seen with lower knowledge, would help in bridging the existing knowledge gap.

\section{REFERENCES}

Amitendu, P., Paraparakath, S. and T. Kaviti. 2019. Zero Budget Natural Farming in Andhra Pradesh: Towards Sustainable and Profitable Farming, Institute of South Asian Studies, No.535 -1

Deepika, M. 2018. Adoption and Marketing Behaviour of Extra Long Table (ELS) Cotton Growers. Unpub. M.Sc. (Ag.) Thesis, AC\&RI, TNAU, Coimbatore.

Iraianbu, V. (2017). Knowledge on Indigenous Cultivation Practices for Sustainable Agriculture. Madras Agricultural Journal. 104(1-3): 98-105.

Mural, S. 2016. "Natural farming can rescue farmers", THE HINDU.

Naresh, R.K., Vivek. and K. Mukesh. 2018. Zero Budget Natural Farming Viable for Small Farmers to Empower Food and Nutritional Security and Improve Soil Health. Journal of Pharmacognosy and Phytochemistry. 7(2):1104-1118.

Palekar, S. 2015. http://www.palekar zero budget spiritual farming.org

Prabhu, K., Jahanara, M. S. and K. Kumar. 2018. Extent of Knowledge of Organic Sugarcane Cultivation Practices in Belgaum district of Karnataka state. Journal of Pharmacognosy and Phytochemistry. 7(3): 1845-1847.

Tripathi, S., Shahidi, T., Shruti, N. and G. Niti. 2018. Zero Budget Natural Farming for the Sustainable Development Goals : Andhra Pradesh, The Council on Energy, Environment and Water, 1-4. 